\title{
ANALISIS KEBANGKRUTAN PERUSAHAAN MANUFAKTUR LQ 45 BURSA EFFEK INDONESIA
}

\author{
Qimyatussa'adah, Dian Kusumaningrum \\ PoliteknikNegeriMadiun \\ qsaadahhafidz@pnm.ac.id
}

\begin{abstract}
Abstrak
Penelitian ini bertujuan untuk memprediksi risiko kebangkrutan pada perusahaan manufaktur yang terdaftar pada LQ 45 Bursa Effek Indonesia. Perusahaan manufaktur menjadi objek penelitian ini karena, perusahaan manufaktur merupakan entitas yang menghadapi tantangan internal dan eksternal yang kompleks. Hal ini disebabkan oleh rangkaian aktivitas bisnis yang dijalankan oleh perusahaan manufaktur yang relatif lebih panjang daripada jenis perusahaan lainnya. Oleh karenanya, perusahaan manufaktur harus terus berupaya untuk memperbaiki tata kelolanya untuk mampu bertahan dan menjamin keberlangsungannya. Data yang digunakan dalam penelitian ini adalah data laporan keuangan seluruh perusahaan manufaktur yang terdaftar pada LQ 45 Bursa Effek Indonesia. Periode laporan keuangan yang digunakan pada penelitian ini adalah laporan keuangan tahun 20014 sampai dengan 2016. Analisis kebangkrutanpada penelitian ini akan menggunakan model penelitian yang digunakan untuk perusahaan menufaktur, yaitu Model Altman (z-score) dan Model Springate. Penggunaan dua model dalam penelitian ini dimaksudkan untuk mengukur konsistensi hasil analisis kebangkrutan pada perusahaan manufaktur jika menggunakan model yang berbeda.
\end{abstract}

Kata kunci :industrimanufakturn, LQ 45, Z-score, S-score.

PENDAHULUAN

Keberlangsungan sebuah entitas merupakan hal utama yang selalu menjadi landasan dalam penentuan arah kebijakan serta tata kelola sebuah entitas. Dalam akuntansi, keberlangsungan atau going concern merupakan dasar asumsi yang tertuang dalam rerangka konseptual pelaporan keuangan. Hal ini menunjukkan bahwa keberlangsungan hidup sebuah entitas merupakan hal yang penting. Keberlangsungan sebuah entitas merupakan keadaan dimana entitas dapat terus menunjukkan eksistensinya pada bidang yang digelutinya. Namun demikian, mempertahankan keberlangsungan sebuah entitas terutama dalam kegiatan bisnis bukanlah hal yang mudah, sebab entitas akan selalu dihadapkan pada risiko kebangkrutan.

Risiko kebangkrutan dihadapi oleh seluruh entitas terutama entitas yang menjadikan pencapaian profit sebagai tujuan utamanya. Oleh karenanya analisis atas risiko kebangkrutan dilakukan secara terus menerus sebagai instrumen untuk pengendalian awal dalam tata kelola entitas. Hasil dari analisisis kebangkrutan dapat menjadi dasar bagi manajemen untuk menentukan langkah yang 
akan memastikan keberlangsungn hidup entitas dan melakukan berbagai upaya untuk mencegah kebangkrutan.

Perusahaan manufaktur sebagai salah satu jenis dari entitas yang menjadikan pencapaian profit sebagai tujuan utamanya memiliki rangkaian aktivitas bisnis yang relatif lebih kompleks dibandingkan dengan jenis perusahaan lainnya. Perusahaan manufaktur melakukan kegiatan produksi untuk kemudian memasarkannya. Dalam prosesnya, kegiatan produksi memerlukan perhitungan yang tepat agar kegiatan operasional produksi dapat terus berlangsung. Perhitungan tersebut meliputi ketepatan akan perhitungan kebutuhan bahan baku; ketepatan estimasi waktu pemesanan bahan baku dimana hal ini penting untuk menjamin bahwa bahan baku yang digunakan adalah bahan baku dengan kualitas terbaik dan tidak kadaluarsa; ketepatan perhitungan kebutuhan tenaga kerja serta berbagai beban operasional lainnya.

Sebagai akibat dari rangkaian aktivitas bisnis yang relatif lebih panjang, maka perusahaan manufaktur menghadapi tantangan yang lebih kompleks dalam upayanya mempertahankan keberlangsungan hidupnya. Oleh karenanya, analisis kebangkrutan atas perusahaan manufaktur menjadi hal yang penting untuk dilakukan.
Lebih jauh, sebagai bagian dari pembelajaran analisis laporan keuangan, penelitian ini melibatkan dua mahasiswa. Keterlibatan mahasiswa dalam penelitian ini diharapkan dapat mengasah kemampuan mahasiswa untuk bisa melakukan analisis laporan keuangan serta mampu memahami kebermanfaatan dari hasil analisis yang dilakukannya sebagai dasar perumusan kebijakan.

Sebagaimana uraian di atas, perusahaan manufaktur menjadi objek pada penelitian ini karena rangkaian aktivitas bisnis perusahaan manufaktur yang lebih kompleks. Dengan pemlihan perusahaan manufaktur sebagai objek penelitian, diharapkan mahasiswa yang terlibat dalam penelitian ini mampu memahami aktivitas bisnis yang kompleks. Pemahaman mahasiswa atas rangkaian aktivitas bisnis pada perusahaan manufaktur dapat membantu mahasiswa untuk memahami secara utuh keterkaitan antara satu mata kuliah dengan mata kuliah lainnya.

Analisis kebangkrutan sebagai bagian dari analisis laporan keuangan atas perusahaan manufaktur akan mendorong mahasiswa untuk memahami akuntansi biaya, manajemen keuangan, akuntansi keuangan dan analisis laporan keuangan secara simultan. Pemahaman atas akuntansi biaya 
akan diperoleh mahasiswa dalam melakukan analisis atas laporan laba rugi perusahaan manufaktur, sebab nilai dari harga pokok penjulan yang disajikan pada laporan laba rugi merupakan hasil perhitungan dari kegiatan operasional produksi, dimana tidak dimiliki oleh jenis perusahaan non manufaktur. Pemahaman mahasiswa atas manajemen keuangan diperoleh ketika mahasiswa melakukan analisis rasio keuangan berdasarkan laporan keuangan. Pemahaman atas akuntansi keuangan diperoleh dari penyajian berbagai komponen atau akun-akun pada laporan keuangan serta catatan atas laporan keuangan, serta pemahaman atas analisis laporan keuangan diperoleh berdasarkan hasil dan pembahasan atas analisis kebangkrutan pada penelitian ini.

Arti penting keberlangsungan hidup sebuah entitas menuntut entitas untuk terus melakukan tata kelola yang tepat. Pelaksanaan tata kelola entitas yang tepat harus didasarkan pada estimasi dan prediksi yang rasional, salah satunya adalah analisis kebangkrutan. Penelitian ini bertujuan untuk mengestimasi dan memprediksi kebangkrutan perusahaan manufaktur yang terdaftr pada LQ 45 Bursa Effek Indonesia.

\section{LANDASAN TEORI}


kondisi yang terhindar dari kebangkrutan sehingga mampu untuk melunasi kewajibannya.Selain itu, berdasarkan hasil analisis ini, kreditur dapat menentukan besaran nominal ideal yang dapat dipinjamkan kepada entitas.

Hasil dari analisis kebangkrutan juga menjadi informasi yang diperlukan oleh investor, sebab investor yang rasional akan berusaha menanamkan modalnya kepada entitas yang akan mampu memberikan keuntungan dan dalam keadaan yang sehat. Selain itu, investor dapat juga menggunakan informasi berdasarkan analisis kebangkrutan untuk membeli atau mengambil alih sebuah entitas sesuai nilai perusahaannya, dengan risiko kebangkrutan yang tinggi maka tentu saja nilai perusahaan akan lebih rendah.

Pemerintah juga dapat memanfaatkan informasi berdasarkan hasil analsisi kebangkrutan untuk mengawasi jalannya perekonomian negara. Jika risiko kebangkrutan sebuah perusahaan dianggap membahayakan penyelenggaraan perekonomian negara, maka pemerintah memiliki kewenangan untuk memberikan dana talangan atau sebaliknya. Profesi akuntan dan auditor juga dapat memanfaatkan informasi dari analisis kebangkrutan untuk menentukan penilaian dan atau opininya atas keberlangsungan hidup entitas untuk memenuhi asumsi going concerns dalam akuntansi.Informasi berdasarkan analisis kebangkrutan juga sangat diperlukan oleh manajemen.Informasi ini menjadi dasar bagi manajemen untuk menentukan kebijakan sesuai kondisi riil perusahaan. Manajemen juga dapat mengambil tindakan untuk mencegah terjadinya kebangkrutan berdasarkan informasi ini.

Riset-riset terdahulu menunjukkan bahwa analisis kebangkrutan dapat menunjukkan hasil yang berbeda apabila model analisis yang digunakan berbeda.Selain itu jenis industri pun dapat mempengaruhi nilai dari risiko kebangkrutan.Prihanthini dan Sari (2013) menguji risiko kebangkrutan pada perusahaan food and beverage yang terdaftar di Bursa Effek Indonesia dengan empat model.Pengujian ini menggunakan Model Grover, Model Altman Z-Score, Springate dan Zmijewski.Hasil pengujian menunjukkan bahwa hasil analisis risiko kebangkrutan memiliki nilai yang berbeda secara signifikan antara penggunaan model yang satu dengan model lainnya.

Demikian pula hal nya dengan Fatmawati (2012) yang menggunakan model Zmijewski, model Altman dan model Springate untuk 
menguji prediktor delisting padaperusahaan yang terdaftar di Bursa Effek Indonesia. Purnajaya dan Merkusiwati (2014) menggunakan tiga model analisis untuk menguji risiko kebangkrutan pada industry kosmetik yang terdaftar di Bursa Effek Indonesia, hasil analisis juga menunjukkan perbedaan nilai risiko kebangkrutan yang signifikan antara satu model analisis dengan model analisislainnya. Model analisis kebangkrutan eratkaitannya dengan rasio keuangan, hal ini diuji oleh Hapsari (2012) dengan hasil penelitian yang menunjukkan bahwa rasio profitabilitas dan leverage berpengaruh signifikan terhadap risiko kebangkrutan.

Nurcahyanti (2015) menggunakan tiga model yang berbeda untuk menguji risiko kebangkrutan pada perusahaan yang terdaftar di Bursa Effek Indonesia, hasilnya menunjukkan bahwa tingkat akurasi model analisis yang satu berbeda dengan yang lainnya. Lebih jauh, hasil analisis Prihanthini dan Sari (2013), Fatmawati (2012), Nurcahyanti (2015), Saputro (2013), Adnan dan Arisudhana (2012), Adrian dan Khoruddin (2014) menunjukkan nilai risiko kebangkrutan pada perusahaan manufaktur dimana terdapat perusahaan yang tergolong 'sehat', ''rawan', dan 'bangkrut',
Cahyono dan Moeljadi (2014) menguji risiko kebngkrutan pada perusahaan pertambangan batubara yang terdaftar di Bursa Effek Indonesia.Hasil penelitian ini menunjukkan bahwa terdapat perusahaan yang sehat dan terdapat perusahaan yang dalam kondisi rawan.

Riset-riset terdahulu menunjukkan adanya perbedaan nilai risiko kebangkrutan yang berbeda ketika model analisis yang digunakan berbeda.Jenis industri juga turut mempengaruhi perbedaan hasil analisis kebangkrutan, oleh karenanya penelitian ini mencoba melakukan analisi dengan menggunakan dua model untuk mengukur konsistensi nilai kebangkrutan sebuah perusahaan.

Riset-riset terdahulu menunjukkan bahwa dalam sebuah industri akan terdapat perusahaan yang mengalami risiko kebngkrutan, namun dalam jumlah yang berbeda dengan perusahaan yang kinerja keungannya sehat. Sehingga dapat dikatakan bahwa tiap industri akan menghadapi tantangan dan risiko kebngkrutan. Oleh karenya, hipotesis pada penelitian ini dirumuskan sebagai berikut:

Hipotesis 1. Industri manufaktur di Indonesia menghadapi risiko kebangkrutani 
Hipotesis 2 Prediksi risiko kebangkrutan perusahaan manufaktur di Indonesia berada pada tingkat risiko sedang (grey area).

\section{METODE PENELITIAN}

Data yang digunakan pada penelitian ini adalah data laporan keuangan perusahaan manufaktur yang terdaftar pada LQ 45 Bursa Effek Indonesia (BEI). LQ 45 merupakan daftar empat puluh lima perusahaan dengan nilai saham terbaik. Laporan keuangan yang digunakan adalah laporan keuangan pada periode 2014 hingg 2016 untuk masingmasing perusahaan.

Analisis kebangkrutan adalah analisis yang digunakan untuk memprediksi apakah sebuah entitas mengalami kondisi yang berisiko mengalami kebangkrutan. Penelitian ini akan menguji apakah perusahaan manufaktur yang terdaftar pada LQ 45 dalam kondisi yang berisiko mengalami kebangkrutan. Serta melakukan prediksi atas risiko kebangkrutan perusahaan manufaktur di masa depan.

Analisis kebangkrutan pada penelitian ini akan menggunakan dua modelyaitu Model Altman (z-score) untuk perusahaan manufaktur dan Model Springate. Dua model analisis ini digunakan dalam penelitian ini untuk menguji konsitensi dari nilai risiko kebangkrutan pada perusahaan manufaktur. Model Altman (z-score) untuk perusahaan manufaktur merupakan pengembangan model instrumen pengukuran risiko kebangkrutan dari Model Z Score pertama. Model ini khusus digunakan pada jenis perusahaan manufaktur. Formulasi dari model ini adalah sebagai berikut:

Z-score $=0,717 \mathrm{X} 1+0,847 \mathrm{X} 2+3,107 \mathrm{X} 3$ $+0,42 \times 4+0,998 \times 5$

Keterangan:

$\mathrm{X} 1$ = networking capital/total asset

$\mathrm{X} 2$ = earnings / total asset

X3 = earning before interest and taxes / total asset

$\mathrm{X} 4=$ book value of equity/book value of total debt

$\mathrm{X} 5=$ sales $/$ total assets

Jika nilai Z-score > 2,9 maka perusahaan manufaktur yang diuji berada pada kondisi 'aman', atau dalam keadaan dimana perusahaan tersebut memiliki kinerja keuangan yang sehat.Jika nila Z-score berada pada kisaran $1,23<\mathrm{Z}<2,9$, maka perusahaan manufaktur yang diuji berada pada kondisi 'rawan', atau dalam keadaan dimana kinerja keuangan yang rentan terhadap kebangkrutan. Jika nila Z-score< 1,23 maka perusahaan manufaktur yang diuji berada pada kondisi ' 'bangkrut'". 
FormulasidariModel Springate(S- jika nilai $S$-score $\geq 0,862$ maka kinerja Score)adalahsebagaiberikut, keuangan perusahaan manufaktur yang diuji $\mathrm{S}$-score $=1,03 \mathrm{X} 1+3,07 \mathrm{X} 2+0,66 \mathrm{X}_{3}+0,4 \mathrm{X} 4$ berada pada kondisi "'sehat',

Keterangan:

$\mathrm{X} 1$ = working capital/total asset

$\mathrm{X} 2$ = earning before interest and tax / total asset

$\mathrm{X} 3$ = earning before tax / current liability

$\mathrm{X} 4$ = sales / total asset

Jika nilai $\mathrm{S}$-score< 0,862 maka kinerja keuangan perusahaan manufaktur yang diuji berada pada kondisi ' 'bangkrut' .Sementara,

\section{HASIL DAN PEMBAHASAN}

Perusahaan yang terdaftar pada Bursa Effek Indonesia (BEI) pada kelompok perusahaan manufaktur dibagi ke dalam tiga sektor yaitu Sektor Industri Dasar dan Kimia; Sektor Aneka Industri dan Sektor Industri Barang Konsumsi. Masing-masing sektor terbagi ke dalam sub sektor, yang disajikan pada tabel berikut

\section{Tabel 4.1}

RekapitulasiJumlah Perusahaan Manufaktur yang Terdaftarpada BEI

Sektor

Sektor
IndustriDasardan
Kimia

Aneka Industri
Sub Sektor

Semen

Keramik, porselendankaca

Logamdansejenisnya

Kimia

Plastikdankemasan

PakanTernak

Kayudanpengolahannya

Pulp dankertas

Lainnya

Mesindanalatberat

Otomotifdankomponennya

TekstildanGarmen
Jumlah

Perusahaan 


\begin{tabular}{|c|c|}
\hline & Alas kaki \\
\hline & Kabel \\
\hline & Elektronik \\
\hline & Makanandanminuman \\
\hline & Rokok \\
\hline & Farmasi \\
\hline 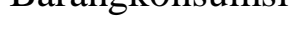 & KosmetikdanBarangKeperluanRumahTangga \\
\hline & PeralatanRumahTangga \\
\hline & Lainnya \\
\hline
\end{tabular}

Sumber : www.idx.co.id

Jumlah perusahaan yang dianalisis pada manufaktur diprediksi berada pada risiko penelitian ini adalah 149 perusahaan. Jumlah kebangkrutan sedang atau grey area. sub sektor pada kelompok perusahaan Hasil analisis kebangkrutan dengan manufaktur sebanyak 21 sub sektor. Analisis menggunakan metode Springate menunjukkan kebangkrutan dengan menggunakan metode hasil yang konsisten dengan analisis Altman menunjukkan bahwa industri pada sub kebangkrutan dengan menggunakan Metode sektor plastik dan kemasan, serta industri pada Altman, dimana perusahaan pada sub sektor sub sektor tekstil dan garmen menghadapi plastik dan kemasan, serta sub sektor tekstil tekanan finansial yang tinggi. Hal ini dan garmen menghadapi tekanan finansila yang ditunjukkan dengan nilai prediksi kebangkrutan tinggi. Perusahaan pada kedua sub sektor ini yang menunjukkan seluruh perusahaan pada diprediksi mengalamai kebangkrutan. Hasil kedua sub sektor ini adalah bangkrut.. analisis dengan metode Springate untuk Sementara, hasil analisis secara keseluruhan seluruh perusahan manufaktur menunjukkan perusahaan manufaktur menunjukkan nilai nilai sebesar -0,946, nilai ini menunjukkan risiko kebangkrutan sebesar 1,92. Nilai ini bahwa seluruh perusahaan manufaktur berada pada risiko sedang atau grey area. Hasil diprediksi mengalami kebangkrutan. Hasil ini mendukung hipotesa 2 bahwa perusahaan analisis dengan menggunakan metode Springate mendukung hipotesis 1 dimana 
perusahaan manufaktur di Indonesia diprediksi berada pada risiko bangkrut.

\section{KESIMPULANDANSARAN}

Saran bagi pelaku industri khususnya pada sub sektor plastik dan kemasan serta tekstil dan garmen adalah perbaikan pada kinerj keuangan. Saran bagi investor, dalam kegiatan berinvestasi agar dapat menanamkan modalnya pada perusahaan yang memiliki resiko tekanan finansial yang rendah.

Kesimpulan

Perusahaan manufaktur pada sub sektor plastik dan kemasan serta tekstildan garmen merupakan perusahaan dengan tekanan finansial yang tinggi dan diprediksi bangkrut. Hasil analisis dengan menggunakan metode Altman mendukung hipotesis 2 dimana perusahaan manufaktur di Indonsia diprediksi berada pada risiko sedang atau grey area. Semenetara hasil analisis dengan menggunakan metode Springate mendukung hipotesis 1 yaitu perusahaan manufaktur di Indonesia diprediksi berada pada risiko bangkrut.

\section{DAFTAR PUSTAKA}

Adnan, Hafidz dan D. Arisudhana. 2012. Analisis Kebangkrutan Model Altman Z-Score dan Springate pada Perusahaan Industri Properti. Jurnal Akuntansi dan Keuangan.

Adrian, A dan M. Khoiruddin. 2014. Pengaruh Analisis Kebangkrutan terhadap Harga Saham Perusahaan Manufaktur. Management Analysis Journal Volume 3 No 1.

Altman, E.I. dan E. Hotchkiss. 2010. Corporate Financial Distress And Bankcruptcy Predict and Avoid Bankcrupty, Analyze and Invest in Distress Debt Third Edition. (E-book Google.com)

Fatmawati, Mila. 2012. The Zmijewski Model, The Altman Model dan The Springate Model sebagai Prediktor Delisting. Jurnal Keuangan dan Perbankan Volume 16 No. 1.

Hapsari, Evanny Indri. 2012. Kekuatan Rasio Keuangan dalam memprediksi Kondisi Financial Distress Perusahaan Manufaktur di Bursa Effek Indonesia. Jurnal Dinamika Manajemen Volume 3 No 2.

Nurcahyanti, Wahyu. 2015. Studi Komparatif Model Z-Score Altman, Springate dan Zmijewski dalam mengindikasikan 
Kebangkrutan Perusahaan yang terdaftar di Bursa Effek Indonesia. Jurnal Akuntansi Volume 3 No 1.

Prihanthini, Ni Made Evi Dwi dan Maria M Saputro,

Ratna Sari. 2013. Prediksi Kebangkrutan dengan Model Grover, Altman Z-Score, Springate dan Zmijewski pada Perusahaan Food and Beverage di Bursa Effek Indonesia. E Jurnal Akuntansi Volume 5 No. 2.

Purnajaya, Komang Devi Methili dan Ni K Lely A. Merkusiwati. 2014. Analisis Komparasi Potensi Kebangkrutan dengan Metode Z-Score Altman, Springate dan Zmijewski pada Industri
Kosmetik yang terdaftar di Bursa Effek Indonesia. E Jurnal Akuntansi Volume 7 No 1.

Sandy Suryo. 2013. Analisis Kebangkruta Perusahaan Manufaktur yang terdaftar di Bursa Effek Indonesia. (eprints.upnyk.ac.id/id/eprint/1209)

Wjaya, Adi Cahyono dan Moeljadi. 2014. Prediksi Kebangkrutan Perusahaan Pertambangan Batubara yang listing di Bursa Effek Indonesia periode 20112012 dengan menggunakan Model ZScore Altman. Jurnal Ilmiah Mahasiswa F.E.B Universitas Brawijaya Volume 1 No 2. 